\title{
THE QUALITY OF GOVERNANCE AND THE POLITICAL CAPACITY OF A COUNTRY: CONTEMPORARY POLISH POLITICAL PARTIES AND THE IDEA OF GOOD GOVERNANCE
}

\begin{abstract}
The capacity of a state in political terms is a relatively new area of political thought. In the debate on the condition of the state, Polish political parties agree on which areas of governance require specific actions on the part of public administration. Politicians have described the desired ways of governing and have formulated concepts of good governance and methods for their implementation. The objective behind this article is to analyze contemporary Polish political thought from two angles - the capacity of a state and its relationship with governance quality. Political thought is analyzed from the perspectives of the system and the problem. The general objective has two sub-goals: (1) to determine the definition and meaning of the term capacity of a state in political thought across various ideological currents (conservative, liberal, people's, social democratic, and nationalist), and (2) to investigate how good governance is defined in the political debate and how it is linked with state capacity.
\end{abstract}

Keywords: good governance, state capacity, political thought, Polish political parties, political debate.

\section{INTRODUCTION}

The capacity of a state in political terms is a relatively new area of political thought. In the debate on the condition of the state, Polish political parties agree which areas of governance require specific actions on the part of public administration. Politicians have described the desired ways of governing and have formulated concepts of good governance and methods for their implementation.

This discussion about the capacity of a state follows findings reported in international scientific literature. The capacity of a state can be understood as the ability to govern, and includes three correlative elements. The first one is policy capacity, which, in very simple terms, is the ability to identify strategic directions for action and to manage the available resources. The second one is administrative capacity, which can be defined as efficient management of the human and physical resources which the state needs in order to function. The third one is state capacity, which focuses on state's relationships with its population,

\footnotetext{
${ }^{1}$ Joanna Sanecka-Tyczyńska, DSc PhD, Maria Curie-Skłodowska University in Lublin, Faculty of Political Science and Journalism, 45 Głęboka St., 20-612 Lublin; e-mail: j.sanecka-tyczynska@poczta.umcs.lublin.pl. ORCID: 0000-0002-0344-4307.
} 
and covers its ability to mobilise social and economic forces in order to achieve its public goals. The capacity of a state can be realised through decision-making, implementation (assigning tasks to state administration), and supervision. (Painter, Pierre, 2005; Fritz, 2007).

Political capacity is associated with the idea of good governance, which has been described extensively in Polish and international literature. In a way, good governance is intended to bring the government closer to its citizens. In line with the principles of democracy and the rule of law, they must not be afraid of governance or definition of their responsibilities, and, moreover, should become involved in these processes and seek to actually influence them. In view of this, scholars have identified six pillars of good governance: (1) democratic rule of law, which guarantees state efficiency; (2) accountability, meaning that governance mechanisms operate in such a way that the authorities and civil servants are responsible for the decisions they make; (3) principle of social inclusion, which guarantees extensive participation of citizens in decision-making across different levels of political power; (4) efficiency and effectiveness, (5) transparency, so that the state operates in an open and transparent manner, and guarantees the availability and clarity of public information, monitoring of public authorities' actions, and clear law-making; and (6) participation, understood as the involvement of citizens and social organisations in state governance. (Weiss, 2000; Rothstein, 2011; Eaton, Akers, 2007; Grindle, 2007; Rotberg, 2014; Ghani, Lockhart, 2008).

The objective behind this article is to analyse contemporary Polish political thought from two angles - capacity of a state and its relationship with governance quality. Political thought is analysed from system and problem perspectives. The general objective has two sub-goals: (1) to determine the definition and meaning of the term capacity of a state in the political thought across various ideological currents (conservative, liberal, people's, social democratic, and nationalist), and (2) to investigate how good governance was defined in the political debate and how it was linked with state capacity.

\section{CONSERVATIVE THOUGHT}

For Law and Justice (Prawo i Sprawiedliwość, PiS), state capacity meant especially internal governance, understood as the ability of the political apparatus to act. And this, in turn, largely depended on the quality of political leadership, including its intellectual abilities, patriotism, and analytical skills (Szczerski, 2010).

The starting point for the discussion about the political capacity of Poland was the assessment of the Third Republic of Poland, which led to the conclusion that following 1989 Poland became a weak state. This negative assessment of Poland as a state was built on four generalisations. (1) In Poland, political power, and the responsibility of the government for the state, became fragmented; (2) Domination of so called transactional politics - especially during the PO-PSL coalition administration in 2007-2015 - understood as a governance philosophy based on "entering into certain agreements and transactions with various pressure groups" (Prawo i Sprawiedliwość, 2015); (3) Moral and competence crisis among the elite and bodies that govern the state was largely responsible for the poor capacity of Poland (Marcinkiewicz, 2005; Matyja, Bugaj, Dorn, 2007); (4) The centre of political power was weakened (Marcinkiewicz, 2005).

For conservatives, this was tantamount to reducing the state to "an arena where different interests and pressure groups can compete", and to excluding citizens from decision- 
making. This situation resulted in the disappearance of political community, replacement of politics with administering, political disputes with expert discussions, and democratic decisions with technocratic solutions. The consequence of this was poor internal coherence of the Third Republic of Poland, which, in the opinion of PiS, became "a confederation of departments", managed by interest groups, lobbyists, professional associations, or local communities (Kaczyński, 2013a). Corporatism, as the source of various pathologies, was considered a threat to the state and citizen freedom.

According to PiS, the poor political capacity of the Third Republic of Poland, actually threatened the existence of the sovereign state. And only a strong and efficient state system, with a great political capacity, could provide citizens with optimum living conditions, combat pathologies, and prevent subjugation to external decision-making centres. In line with its raison d'etat, the state was to mobilise forces and resources for the purposes of social and economic projects, act for the common good, which was the basis for what is known as pragmatic legitimacy (Kaczyński, 2013b).

In addition to the negative assessment of the Third Republic of Poland, PiS argued for the inevitability of the transformation of the contemporary state, which has lost its monopoly over decision-making by becoming one of many centres and sources of power. In the global world, the role of state authority was losing its importance, as states, as the elements of the global network, were to some extent dependent on international organisations and global corporations. PiS politicians were aware that the weaker the state was, the worse its position was in this network (Prawo i Sprawiedliwość, 2019; Staniszkis, 2003).

It seemed natural to reform state structures to ensure its high capacity and efficiency, central government supervision over the processes taking place within the state, and to maintain social cohesion. Good governance was to be the answer to the challenges related to state management. It included five elements. The first was to include businesses and citizen organisations in decision-making for the state administration to appropriately respond to any local "impulses". The second element was to improve management in administration and to introduce strategic planning. The third was a "flexible" model of the public service, aligned with the professional development of the personnel in private companies, involving personnel mobility. Administration was to be oriented towards high quality rather than "stability and routine", as in closed professions. The fourth element of the improvement in state management quality was to be a structural reform of the administration, and the fifth, an improvement in the transparency of administrative decision-making, fight against corruption, and aligning the work of civil servants to business-like quality management principles (Kaczyński, 2019; Błaszczak, 2008). But this idea has never been introduced in practice.

\section{LIBERAL AND SOCIAL DEMOCRATIC THOUGHTS}

Civic Platform (Platforma Obywatelska RP, PO), a representative of the liberal current, similarly to most political parties, associated the political capacity of the state primarily with its capacity for efficient management, i.e. effective making and implementation of political decisions. What was especially important for PO was the state's institutional capacity, which is part of political capacity. It was defined as the efficiency of the government across various areas of internal, international, and European policy, and reasonable management of public administration resources, resulting in improved work 
quality and reduced costs of labour (Platforma Obywatelska RP, 2007b). The efficiency of administration and the judiciary, and the consistency and stability of the legislation, were to help strengthen social capital and develop entrepreneurship (Kancelaria Prezesa Rady Ministrów, 2013).

The views represented by PO were influenced by the evaluation of the reality in the Third Republic of Poland, which emphasised negative phenomena that affected state capacity. Those included the arbitrariness of administrative decisions, corruption, politicisation of the public service, lack of civil servants' responsibility for the consequences of their poor decisions or negligence, and low social trust in public institutions The state crisis was to be tackled by directing the changes in administration towards increasing civil liberties and empowering citizens, rather than strengthening central political institutions (Platforma Obywatelska RP, 2006; Platforma Obywatelska RP, 2007b; Platforma Obywatelska RP, 2011).

High state capacity meant "opening up to citizens." A high capacity state had four important characteristics which were to positively affect the citizen-state relations. These were helpful, friendly, participatory, and transparent. The helpful state was to support the development of social capital, ensuring the enforcement of civil rights and liberties, and citizen creativity and independence, while also respecting their privacy. The "network society" born this way was to contribute to the development of participatory democracy. The construction of the friendly state was to involve changing its modus operandi to more open, based on bilateral communication with citizens. Participatory meant easy access to knowledge and involvement in the exercise of power via social consultations and public debates. Finally, the transparent state was to "explain its decisions in a way that was clear and easy to understand for all citizens", rather than just making them. All the proposed changes were designed to ensure civil liberties and local governments, in collaboration with government administration, deregulation, simplification, and qualitative improvement of legislation to make it more useful for citizens (Platforma Obywatelska RP, 2011).

PO put special emphasis on two approaches to state management. The first was the idea of good governance. The outline of a good governance strategy was included in two key documents prepared by the Ministry of Regional Development and the Ministry of Administration and Digitisation after the PO-PSL coalition rose to power in 2007. It included specific measures for two areas, legal/institutional and civil, especially concerning the relations between the state and citizens. In the first area the priority was to decentralise the state and to have governance rely on cooperation between the government and local governments, NGOs, and various communities (business, scientific etc.) (Ministerstwo Rozwoju Regionalnego, 2007; Platforma Obywatelska RP, 2007a). In the second area, PO focused on regaining Poles' trust in state institutions. On the one hand, the party recognised the negative consequences of the lack of state administration's trust in citizens, which resulted in inconsistent new law. And on the other hand, citizens were found to have no trust in one another and in public institutions. The directions for action identified in government strategies were expected to improve the quality of social and civil skills among Poles (including an improvement in their ability to collaborate), increase social participation and cultural activity, and unlock their creative potential, understood as artistic abilities and technical skills (Platforma Obywatelska RP, 2005; Kancelaria Prezesa Rady Ministrów, 2013).

Another approach to state management was New Public Management (Platforma Obywatelska RP, 2007a). Its guiding principle was to give priority to the art of management 
over the art of administration, and its goal was to achieve a high quality of delivered public services oriented towards the needs and expectations of citizens, who were treated as "administration clients" (Młodzik, 2015). This way, PO wanted to abandon the traditional (bureaucratic) public administration, based on the Weberian model (Marchewka-Bartkowiak, 2014). However, PO was not able to implement this idea in practice.

Similarly as for liberals, for social democrats a high state capacity was to serve especially citizens. According to social democrats, the power of a state, in terms of this capacity, was to be expressed as efficiency and help extended to its citizens, rather than as "being suspicious and controlling". A state with a considerable political capacity was based on social trust. This considerable political capacity could be achieved mainly through political means, and especially state democratisation, respecting human rights, and free functioning of NGOs. Efficient functioning of state structures was predicated on the ability to gather and process information, uninterrupted decision-making, capability to respond in emergency situations, and a citizen-friendly attitude, which makes administrative matters easy to handle (Sojusz Lewicy Demokratycznej, 2011; Sojusz Lewicy Demokratycznej, 2010).

\section{PEASANT THOUGHT}

In the political thought of Polish Peasants' Party (Polskie Stronnictwo Ludowe, PSL) the starting point for the discussion on state capacity was assigning it the role of the key social institution, "the partner and ally of every citizen" (Polskie Stronnictwo Ludowe, 2007). PSL's assessment of Poland's capacity included the fundamental problems of the Polish state. These included, in particular, poor efficiency of political institutions, especially in the economic domain, and a crisis of parliamentary government, which manifested itself in the lack of citizens' trust in the political class. In PSL politicians' view, this poor institutional capacity blocked the economy. The dominant view was that introducing a democratic system and establishing economic and political institutions was not enough for the institutional capacity of the state to drive development. An important addition were "clear rules of the game", such as speed, efficiency, rule of law, and integrity. This would guarantee an environment that is conducive to citizen initiatives and aspirations, and ensures efficient management of public funds by competent public and local government institutions (Polskie Stronnictwo Ludowe, 2008).

Peasant party members associated two things with state capacity. The first was efficient functioning of democratic state (across all levels of power). And the second was the involvement of local governments and citizens organised into social organisations and NGOs in decision-making processes. An efficient democratic state was considered prerequisite for defending and advancing Polish national interests in the face of globalisation and integration. And local governments was seen as "the school of efficiency and subjecting politics to the interests of local communities". This was to serve as the foundation for building a positive image of politics as an important social activity. Two types of action were proposed - eliminating "empty rhetoric and social engineering without an ideology", and supporting civic participation and social involvement (Polskie Stronnictwo Ludowe, 2008).

PSL considered the loss of social trust in the political class and the lack of agreement between parties on crucial raison d'etat matters as factors that made it difficult to take strategic action, make political decisions, carry out reforms, and bringing society round to 
them. It was considered particularly dangerous for state's existence to putting current party interests above state ones, and preferring tactical over strategic action consistent with Polish raison d'etat (Kalinowski, 2003).

Corruption, one of important social problems, was to be curbed by introducing the transparency of decision-making procedures, including in public procurement and privatisation agreements, and the obligation of high-ranking government officials to disclose their previous positions with public authorities or businesses. The goal behind these measures was to be the transparency of state institutions and tackling corruption (Polskie Stronnictwo Ludowe, 2004). These objectives were in opposition to political practices. In reality, PO-PSL coalition followed the policy of weakening the role of citizens by depriving them of any influence over governance. With a significant majority of society believing that Poland was less and less the state of the sovereign, and the means of sovereign expression, Platforma Obywatelska and Polskie Stronnictwo Ludowe lost in the 2015 election (Gazeta Wyborcza, 2012; Rzeczpospolita, 2013).

\section{NATIONALIST THOUGHT}

League of Polish Families (Liga Polskich Rodzin, LPR) also described state capacity as meaning efficient and effective state institutions (Dobrosz, 2007). State effectiveness was about being able to accomplish state's policies based on national interests, and relied on taking actions across three areas - assessment of reality, methodology of change, and implementation of decisions. What was important was to accurately evaluate the state in terms of its social and economic situation to identify any problems, to select methods and tools for addressing those, and to implement political decisions in an undisturbed manner.

The starting point for the development of a good governance concept by LPR was the assumption that the state was only an instrument and that it was the property of the nation, and an expression of its will to exist and function within a common organisational structure. Therefore, a strong and effective state with a high political capacity corresponded to "efficient organisation of the nation", based on citizens' responsibility for the quality of state structures. It was not possible to "heal" Poland "without healing it at grassroots level". So, on the one hand, it was important to secure professional resources in the form of competent public service members, and on the other hand, efficiently enforce the law. Civil servants and regular citizens were to share "concern for the wellbeing of their homeland, public service, and lawmaking that generates consistent, logical, and society-serving regulations". In a strong state, citizens would universally trust political institutions (Dobrosz, 2004; Dobrosz, 2005; Giertych, 2008).

Importantly, nationalistic state was to be a strong organisation "not to protect itself against citizens, but to protect its citizens against threats, such as internal (police) and external (army) banditry. We grant power to the state so that it protects our nation, our families, and each of us individually" (Giertych, 2005). Only a strong state, build on truth and justice, could gain social trust. Any devolutionary factors that could weaken the state and its structures, such as anti-state activities of the power elite, political parties, and international organisations, were opposed.

It was argued, that the low capacity of the Third Republic of Poland was due to the poor condition of the elite, who were characterised by an anti-state mentality and lack of patriotism, who showed disrespect for ethics and morality, and treated power as a chance to get rich easily. In their behaviour, they flouted the principle of equality in the eyes of the 
law and social justice. This criticism against the political elite also included the lack of intellectual qualities and skills necessary for serving major public functions, and reliance on external decision-making centres.

\section{CONCLUDING REMARKS}

The analysis of the expressions of contemporary Polish political thought from the perspective of state capacity and methods for governing public institutions leads to three conclusions.

Firstly, politicians have recognised that attention to state capacity, meaning de facto its condition, is among the most important state interests. On the one hand, political capacity, defined as the effectiveness and power of institutions, efficient decision-making and implementation, determines state existence and development. But on the other hand, for state interests to be advanced, the state needs to be strong and have efficient executive instruments. What is equally important is the ability to define values, needs, interests, and goals underlying state policies and strategies. Whether a state can fulfil its fundamental functions actually decides its survival. Weak states (with low capacity) are more vulnerable to losing their primary attributes of sovereignty, weakening their institutional capacity, and becoming dependent on strong members of the international system. Consequently, it is crucial for state existence to improve state capacity across many areas.

Secondly, in the political thought of contemporary political parties in Poland there was a consensus that government authorities had to constantly enhance state functioning so that the state could serve its purpose without let or hindrance. The factors that were most often cited as preventing the state from operating efficiently were poor political elite, corruption, politicians acting in party and individual interests rather than furthering raison d'etat, inefficient public administration, bureaucracy, social conflicts, mutual blocking of various decision-making centres, etc.

Thirdly, there are three main approaches that emerge from the many political statements about state capacity. The first, traditional and state-centric, represented by PiS, assumes strengthening of state power at the expense of other decision-making centres (civil, localgovernment, and international). State capacity is associated with building a strong state organisation, which is as powerful as its institutions. Liberals, peasant party members, and social democrats, proponents of the second approach, argued that the primary beneficiaries of changes in governance were citizens. A strong state, with interconnected areas of competence, implemented at different levels of governance, including state, local-government, and community levels, was to serve citizens first. The third approach, characteristic of the nationalist political thought, associated state capacity with an efficient organisation of the nation. The efficacy of political power corresponded to the ability to accomplish the goals of state policy, which were based on national interests.

\section{REFERENCES}

Błaszczak, M. (2008). The shorthand report from the 26th session of the Sejm of the Republic of Poland [Access: 10.03.2021]. Access on the internet: http://orka2.sejm.gov.pl/Debata6.nsf/ main/1366E8CF

Dobrosz, J. (2004). The shorthand report from the 78th session of the Sejm of the Republic of Poland [Access: 10.03.2021]. Access on the internet: https://orka2.sejm.gov.pl/Debata4. 
nsf/5c30b337b5bc240ec125746d0030d0fc/720c0e143a283157c1257478004690df?Open Document

(2005). The shorthand report from the 95th session of the Sejm of the Republic of Poland [Access: 11.05.2021]. Access on the internet: http://orka2.sejm.gov.p1/Debata4.nsf/ main/3A92D6CE

- (2007). The shorthand report from the 41st session of the Sejm of the Republic of Poland [Access: 10.03.2021]. Access on the internet: http://orka2.sejm.gov.p1/Debata5.nsf/ main/007C91CA

Eaton, T. V., Akers, M. D. (2007). Whistleblowing and Good Governance."CPA Journal 77' No. 6.

Fritz, V. (2007). State-Building. A Comparative Study of Ukraine, Lithuania, Belarus and Russia. Budapest: Central European University Press.

Gazeta Wyborcza (2012). Sejm. »Nie« dla referendum w sprawie podwyższenia wieku emerytalnego [Access: 27.05.2021]. Access on the internet: https://wyborcza.pl/ $1,75398,11448974$, Sejm__Nie_dla_referendum_w_sprawie_podwyzszenia.html

Ghani, A., Lockhart, C. (2008). Fixing Failed States. A Framework for Rebuilding A Fractured Word. Oxford University Press.

Giertych, M. (2005). Z nadzieja w przyszłość. Warszawa: Wydawnictwo Ars Politica.

— (2008). Moralność na co dzień. "Opoka w Kraju”, No. 68.

Grindle, M. (2007). Good Enough Governance Revisited "Development Policy Review", Vol. 25.

Kaczyński, J. (2013a). Chcę uratować Polskę przed dwiema katastrofami. ”Do Rzeczy”, No. 21.

— (2013b). Żeby Polska mogła trwać, trzeba ja przebudować. I to musi być zmiana bardzo daleko idaca [Access: 17.05.2020]. Access on the internet: https://wpolityce.pl/polityka/ 156651-premier-jaroslaw-kaczynski-dla-wpolitycepl-na-swieto-konstytucji-3-maja-zebypolska-mogla-trwac-trzeba-ja-przebudowac-i-to-musi-byc-zmiana-bardzo-daleko-idaca

— (2019). Żeby dobrze rzadzić, trzeba być kompetentnym i uczciwym [Access: 17.05.2020]. Access on the internet: https://businessinsider.com.pl/wiadomosci/j-kaczynski-zebydobrze-rzadzic-trzeba-byc-kompetentnym/n326y 77

Kalinowski, J. (2003). The shorthand report from the 54th session of the Sejm of the Republic of Poland [Access: 05.05.2021]. Access on the internet: http://orka2.sejm.gov.pl/Debata4.nsf/ main/0EB7C097

Kancelaria Prezesa Rady Ministrów (2013). Polska 2030. Trzecia fala nowoczesności. Dtugookresowa Strategia Rozwoju Kraju [Access: 11.03.2021]. Access on the internet: http://polska2030.pl/dlugookresowa-strategia-rozwoju-kraju-polska-2030-trzecia-falanowoczesnosci/

Marchewka-Bartkowiak, K. (2014). Nowe zarzadzanie publiczne. "Infos", No. 18.

Marcinkiewicz, K. (2005). The shorthand report from the 2 nd session of the Sejm of the Republic of Poland [Access: 10.03.2021]. Access on the internet: http://orka2.sejm.gov.pl/ Debata5.nsf/main/6925B14F

Matyja, R., Bugaj, R., Dorn, L. (2007). Jaka prezydentura? ”Nowe Państwo", No. 1.

Ministerstwo Rozwoju Regionalnego (2007). Narodowe Strategiczne Ramy Odniesienia 2007-2013 [Access: 19.07.2020]. Access on the internet: https://stat.gov.pl > gfx > poz_za. 5_nsro.pdf

Młodzik, E. (2015). Założenia koncepcji New Public Management. ”Wspótczesne Problemy Ekonomiczne", No. 11. DOI: 10.18276/wpe.2015.11-17 
Painter, M., Pierre, J. (2005). Unpacking Policy Capacity: Issues and Themes [In:] Painter, M., Pierre, J., eds., Challenges to State Policy Capacity. Global Trends and Comparative Perspectives. Palgrave Macmillan UK, p. 1-18.

Platforma Obywatelska (2005). Państwo dla obywateli. Plan rządzenia 2005-2009 [Access: 10.09.2020]. Access on the internet: https://www.dobrowol.org/drobiazgi/Panstwo_ dla_obywateli.pdf

(2006). PO stronie obywateli. Uchwata III Krajowej Konwencji Platformy Obywatelskiej $R P$ [Access: 19.07.2019]. Access on the internet: http://www.platforma.org/uchwały/ PO-stronie-obywateli/

(2007a). Polska Obywatelska. Podstawy programu politycznego Platformy Obywatelskiej $R P$ [Access: 19.07.2020]. Access on the internet: http://www.zientarski.pl/pliki/ artykuly/artykul_38_1301443909_zalacznik_sciezka.pdf

_ (2007b). Polska zastuguje na cud gospodarczy [Access: 10.03.2019]. Access on the internet: http://www.platforma.org/program/

(2011). Następny krok. Razem. Program wyborczy Platformy Obywatelskiej RP [Access: 21.07.2020]. Access on the internet: http://www.szejnfeld.pl/index.php/analizy/nastepnykrok-razem-zalozenia-ideowe-programu-wyborczego-platformy-obywatelskiej/

Polskie Stronnictwo Ludowe (2004). Naród, Państwo, Człowiek, Środowisko. Wizja, misja i priorytety programowe Polskiego Stronnictwa Ludowego. VIII Kongres Polskiego Stronnictwa Ludowego [Access: 11.04.2017]. Access on the internet: https:// zachodniopomorskie.psl.pl/dokumenty-kongres/

- (2007). Razem tworzymy lepsza przyszłość. Narodowe priorytety PSL na lata 2007-2011 [Access: 27.07.2019]. Access on the internet: http://www.psl.pl/upload/pdf/dokumenty/ priorytety_1_.pdf

_ (2008). Dokumenty X Kongresu Polskiego Stronnictwa Ludowego [Access: 27.02.2021]. Access on the internet: https://docplayer.pl/1962924-Dokumenty-X-kongresu-psl.html

Prawo i Sprawiedliwość (2014). Zdrowie. Praca. Rodzina. Program Prawa i Sprawiedliwości [Access: 11.03.2021]. Access on the internet: http://pis.org.pl/dokumenty

- (2015). Jarosław Kaczyński na spotkaniu z Akademickim Klubem Obywatelskim im. Lecha Kaczyńskiego w Poznaniu [Access: 12.06.2019]. Access on the internet: old.pis.org.pl (2019). Polski model państwa dobrobytu. Program Prawa i Sprawiedliwości [Access: 11.03.2021]. Access on the internet:file:///C:/Users/HP/AppData/Local/Temp/Program $\% 20 \mathrm{PiS} \% 202019 . \mathrm{pdf}$

Rotberg, R. (2014). Good Governance Means Performance and Results. "Governance - An International Journal of Policy, Administration and Institutions", Vol. 27.

Rothstein, B. (2011). The Quality of Government. Corruption, Social Trust and Inequality in International Perspective. Chicago: University of Chicago Press.

Rzeczpospolita (2013). Sejm odrzucit wniosek o referendum ws. sześciolatków w szkołach [Access: 27.07.2019]. Access on the internet: https://www.rp.pl/artykul/1059379-Sejmodrzucil-wniosek-o-referendum-ws-szesciolatkow-w-szkole.html

Sojusz Lewicy Demokratycznej (2010). Lewica dla Polski [Access: 27.07.2019]. Access on the internet: https://cpofpoland.files.wordpress.com/2013/06/lewica-dla-polski.pdf (2011).Zmian@ - Cyfrowa Polska 2011-2015 [Access: 27.07.2019]. Access on the internet: http://www.rksld.home.pl/uploads/pliki/PROGRAM_Zmiana_-_Cyfrowa_ Polska_2011-2015.pdf

Staniszkis, J. (2003). Wtadza globalizacji. Warszawa: Wydawnictwo Scholar. 
Szczerski, K. (2010). Jakość struktur państwa a jego zdolność do realizacji polityki zagranicznej [Access: 18.02.2021]. Access on the internet: https://www.omp.org.pl/artykul.php? artykul $=230$

Weiss, T. G. (2000). Governance, Good Governance and Global Governance. Conceptual and Actual Challenges. „Third World Quarterly”, Vol. 21.

DOI: 10.7862/rz.2021.hss.25

The text was submitted to the editorial office: June 2021.

The text was accepted for publication: September 2021. 